\title{
Expression Level of Annexin A1 Contributes to the Evaluation of the Disease Progression and Treatment Effect of Lung Adenocarcinoma: A New Perspective from Retrospective Analysis
}

\section{Biaoxue Rong ( $\square$ research568rbx@yeah.net )}

Xi'an Medical University

Hongling Yan

Xi'an Medical University

Ge Wu

Xi'an Medical University

Kai Li

Xi'an Medical University

Min Li

Shenmu Hospital

Congxue Rong

Zhangye Second People Hospital

Wen Liu

Minqin County People's Hospital

\section{Research Article}

Keywords: Annexin A1, lung adenocarcinoma, LAC, disease progression, treatment

Posted Date: April 28th, 2021

DOI: https://doi.org/10.21203/rs.3.rs-401429/v1

License: (c) (1) This work is licensed under a Creative Commons Attribution 4.0 International License. Read Full License 


\section{Abstract}

Background: Increased Annexin A1 has been showed to be related to malignant biological characteristics of tumors; the aim of this study was to evaluate the relationship between the expression level of Annexin A1 and the disease progression and treatment effect of lung adenocarcinoma (LAC).

Methods: The expression level of Annexin A1 in LAC tissues and cells was detected by the methods of immunohistochemistry, Real time-PCR and western blotting. The relationship between the expression of Annexin $\mathrm{A} 1$ and the disease progression and treatment effect of LAC was evaluated by descriptive statistics, $T$ test and Chi-square test.

Results: The protein expression of Annexin A1 was higher in lung cancer tissues and cells than that in normal tissues and 16 human bronchial epithelial (16HBE) cells $(p<0.05)$. The level of Annexin A1 mRNA was higher in lung cancer tissues than that in normal tissues $(p<0.05)$. The increase of Annexin A1 protein and mRNA was associated with the lymph node metastasis, advanced clinical stage $(p<0.05)$. However, surgical resection and chemotherapy for LAC down-regulated the serum concentration of Annexin A1 in patients $(p<0.05)$.

Conclusions: Increased Annexin A1 protein and mRNA in LAC tissues correlate with the poor differentiation, lymph node metastasis and advanced stage of LAC. Surgical resection and chemotherapy for LAC down-regulate the serum concentration of Annexin A1 in patients. The results indicate that expression level of Annexin A1 contributes to the evaluation of the disease progression and treatment effect of LAC.

\section{Background}

Lung cancer is a kind of disease that threatens human's health and lives severely, especially in developing country, China. Despite recent advances in new diagnostic techniques and individualized treatment, lung cancer is still a very malignant disease characterized by a high incidence of mortality [1]. Lung cancer is classified into small cell lung cancer (SCLC, about 15\%) and non-small cell lung cancer (NSCLC, about $85 \%)$. The main histological subtypes of NSCLC are lung adenocarcinoma (LAC) and lung squamous cell carcinoma (LSCC) [2]. Today, molecular targeted therapy based on gene mutation and abnormal protein expression has gradually exerted a definite effect in the treatment of LAC. So, identifying the genes and molecular signal pathways involved in LAC is important basic and translational research problems $[3,4]$. Although the diagnosis and treatment of LAC has made some progresses, the long-term survival of patients are still not optimistic. An in-depth understanding of the molecular biology of LAC may be of help in developing more effective and specific diagnostic methods and therapeutic drugs.

Annexin A1 is a Ca-dependent phospholipid binding protein encoded by the human Annexin A1 gene, with a molecular weight of about $40 \mathrm{kDa}$, and has phospholipase $\mathrm{A} 2$ inhibitory activity. Existing research reports show that Annexin A1 is related to the occurrence and development of tumors, but its carcinogenic effects and mechanisms in different malignant tumors are still unclear [5-7]. Annexin A1 
expression has been up-regulated in some cancers, but down-regulated in other cancer types. These abnormal expressions all show an inherent connection with the occurrence and development of these tumors [5, 7]. In breast cancer, changes in the expression level of Annexin A1 suggest a potential impact on tumorigenic and metastatic processes. However, reports of conflicting results indicate that this relationship is much more complicated than initially conceptualized [5]. A more consistent understanding of Annexin A1 in cancer may lead to more biologically meaningful and clinically relevant strategies [6-8]. Previously, we found that Annexin A1 had a significant increase in LAC cells as compared with the 16 human bronchial epithelial (16HBE) cells. In this study, we investigated the relationship between the expression of Annexin A1 and the disease progression and treatment effect of LAC.

\section{Methods}

\section{Collection of tissue specimens and production of tissue chips}

From January 2018 to October 2020, 102 patients from First Affiliated Hospital, Xi'an Medical University and Zhangye People's Hospital who had undergone lung cancer resection were included in this study (Table 1). The study was approved by the institutional review committee (First Affiliated Hospital, Xi'an Medical University), and written informed consent was obtained from all subjects. The matched adjacent tissues (from the edge of tumor mass at least $3 \mathrm{~cm}$ away) were selected as normal control. The tissue chips was constructed using the collected tissues. The steps were as follows: (1) marking the morphologically representative tumor area; (2) using a hollow needle with a diameter of $2 \mathrm{~mm}$ to cut the tissue strip from the donor wax block; (3) placing the tissue strip in the recipient wax block according to the specific allocated position; and (4) cutting $5 \mu \mathrm{m}$ thick tissue slices and drying for use. 
Table 1

Characteristics of included patients $(\mathrm{n}=102)$

\begin{tabular}{|c|c|c|}
\hline Items & Characteristics & lung adenocarcinoma $(\mathrm{N}=102)$ \\
\hline \multicolumn{3}{|l|}{ Sex } \\
\hline & Male & $70(68.6 \%)$ \\
\hline & Female & $32(31.4 \%)$ \\
\hline \multicolumn{3}{|l|}{ Age } \\
\hline & $<60$ & $68(66.7 \%)$ \\
\hline & $\geq 60$ & $34(33.3 \%)$ \\
\hline \multicolumn{3}{|c|}{ Smoking } \\
\hline & Yes & $40(39.2 \%)$ \\
\hline & No & $62(60.8 \%)$ \\
\hline \multicolumn{3}{|c|}{ Pathological differentiation } \\
\hline & Poor & $42(41.2 \%)$ \\
\hline & Moderate & $38(37.3 \%)$ \\
\hline & Well & $22(21.6 \%)$ \\
\hline \multicolumn{3}{|c|}{ Lymphatic invasion } \\
\hline & Yes & $38(37.3 \%)$ \\
\hline & No & $64(62.7 \%)$ \\
\hline \multicolumn{3}{|c|}{ Clinical staging } \\
\hline & IIA & $62(60.8)$ \\
\hline & IIB & $36(35.3 \%)$ \\
\hline & IIIA & $4(3.9 \%)$ \\
\hline $\mathrm{N}$, pati & & \\
\hline
\end{tabular}

\section{Immunochemistry (IHC)}

Immunohistochemical method was used to detect the expression level of Annexin A1 protein in LAC tissue and normal tissues adjacent to cancer. Specific steps are as follows. The slices were dewaxed and hydrated, and soaked in $3 \% \mathrm{H}_{2} \mathrm{O}_{2}$ for $10 \mathrm{~min}$. The antigen in the tissue on slices was repaired by method of microwave heating. The slices was blocked with serum, then incubated with the primary antibody (Annexin A1 rabbit anti-human polyclonal antibody 1:100; BOSTER Biological Technology co.Itd, Wuhan, China). After rinsing with PBS the next day, the slices were incubated with a secondary antibody (biotin- 
labeled secondary antibody 1:200). Avidin working solution was dropped on the slices to stop the reaction. The slices were dehydrated using gradient alcohol and mounted by neutral gum. The positive slices for breast cancer provided by the kit served as the positive control, PBS solution instead of primary antibody was used as a negative control. Two pathologists used a blind method to evaluate the results of IHC reference to previously published research [9]. The intensity was graded according to the following scale: 0 , no staining; $1+$, mild staining; $2+$, moderate staining; $3+$, intense staining. The extent was evaluated as follows: 0 , no staining of cells in any microscopic fields; $1+,<30 \%$ of tissue stained positive; $2+$, between $30 \%$ and $60 \%$ stained positive; $3+,>60 \%$ stained positive. A combined staining score (intensity + extension) of $\leq 2$, between 3 and 4 , and between 5 and 6 were considered as low, moderate, and high expression levels, respectively [10].

\section{Real-time quantitative PCR}

According to the instructions of the Total RNA extraction kit, the total RNA was extracted from lung tissues. The Gene quact $\otimes$ colorimeter (Pharmacia Biotech, USA) was employed to determine the total RNA concentration. The agarose gel electrophoresis (1.2\%) was used to detect the integrity of total RNA. The M-MLV first-strand synthesis system kit was used to reverse transcription to synthesize cDNA and a LightCycler®480 thermal cycler (Roche) was used to perform Real-Time PCR experiments. The upstream primer sequence of Annexin A1: 5'-TCCCGTTCTGAAATTGACATGA-3', downstream primer sequence: 5'TCTCATAATCTCCTTTGGTTTCATC-3', product size: $106 \mathrm{bp}$; The sequence of the upstream primer of the internal reference gene $\beta$-actin: 5'-GTTGCTATCCAGGCTG TG-3', downstream primer sequence: 5 'TGTCCACGTCAC ACTTCA-3', product size: 465 bp.

\section{Enzyme-linked immunosorbent assay (ELISA)}

We collected $10 \mathrm{~mL}$ of cubital venous blood from patients on an empty stomach in the morning, centrifuged at $3000 \mathrm{rpm}$ for $10-15$ minutes, and collected the supernatant for cryopreservation at $-70^{\circ} \mathrm{C}$. A rabbit anti-human Annexin A1 sandwich ELISA test kit developed by China Xitang Biotechnology Company (CK-E91728H) was used to measure the level of serum Annexin A1. The serum samples diluted in PBS ( $\mathrm{pH} 7.4$ ) containing 1\% BSA were coated in 96-well plates, and then $10 \mathrm{ng} / \mathrm{mL}$ monoclonal antiAnnexin $\mathrm{A} 1$ antibody were dropped into the small wells and incubated at $37^{\circ} \mathrm{C}$ for 1 hour. The substrate reagent was reacted with avidin-coupled peroxidase at $37^{\circ} \mathrm{C}$ for 15 minutes. The $50 \mu \mathrm{l}$ of $2 \mathrm{~N}$ sulfuric acid was added to each well to stop the color reaction, and then the intensity of the color was determined with an ultraviolet spectrophotometer at a wavelength of $450 \mathrm{~nm}$. The measurement standard curve of the test is drawn by using the concentration of the standard sample and the corresponding OD value of each well.

\section{Cells}

The sixteen human bronchial epithelial cells (16HBE) were purchased from the Tumor Cells Collection, Academy of Chinese Medical Sciences, Beijing, China. The human LAC PC-9 and A549 cells were provided by the Experimental Center, Medical School, Xi'an Jiaotong University, China. The cells were incubated in RPMI 1640 medium (containing $100 \mathrm{kU} / \mathrm{L}$ penicillin, $100 \mathrm{mg} / \mathrm{L}$ streptomycin) containing 10\% fetal bovine serum (Procell Life Science \& Technology Co.,Ltd.) in a 37.5\% CO2 incubator. 


\section{Western blot}

The total protein in the tissues and cells was extracted, and the concentration of the protein was detected by the BCA method. The quantified protein was loaded, electrophoresed, transferred, blocked, incubated with the primary antibody (rabbit anti-human Annexin A1 antibody, 1:500 dilution; BOSTER Biological Technology, Wuhan, China) and incubated with the second antibody (goat anti-rabbit 1:1000) step by step. After washing PBS solution, positive signal was visualized using the enhanced chemiluminescence method and exposed with X-ray film. The exposed film was developed with developer and fixer. Finally, the Image $J$ software used to calculate the band gray value of the film. The test of $\beta$-actin was used as the internal control.

\section{Statistical analysis}

The data were divided into two types: counting data and measurement data. The count data were expressed using a composition ratio (\%) and analyzed using chi-square test and Fisher's exact test. The measurement data was expressed by $\mathrm{X} \pm \mathrm{S}$, the comparison between the two groups of means was performed by $t$ test, and the comparison between the means of the two groups or more was determined by single factor analysis of variance. The SPSS 21.0 statistical software was used to perform the data analysis, and the $p<0.05$ was confined as meaningful statistical difference.

\section{Results}

\section{Expression of Annexin A1 in LAC tissues is higher than that in normal lung tissues}

As shown in Table 2, the Annexin A1 was expressed in cytoplasm with staining as yellow and brown (Figs. 1A - D). The expression of Annexin A1 was higher in the LAC tissues $(45.1 \%, 46 / 102)$ than in cancer-adjacent normal tissues $(10.8 \%, 11 / 102)(p<0.001)$ (Fig. 1E). 
Table 2

Correlation between clinico-pathological features and the expression of Annexin A1 in lung adenocarcinoma $(n=102)$

\begin{tabular}{|c|c|c|c|c|c|c|c|}
\hline \multirow[t]{2}{*}{ Items } & \multirow[t]{2}{*}{ Group } & \multirow[t]{2}{*}{$\mathbf{N}$} & \multicolumn{5}{|c|}{ Expression of Annexin A1 } \\
\hline & & & Low (\%) & $\begin{array}{l}\text { Moderate } \\
\text { (\%) }\end{array}$ & High (\%) & $\begin{array}{l}\chi^{2} \\
\text { value }\end{array}$ & $\begin{array}{l}P \\
\text { value }\end{array}$ \\
\hline \multicolumn{8}{|c|}{ Resource } \\
\hline & Normal & 102 & $61(59)$ & $30(29.4)$ & $11(10.8)$ & \multirow[t]{2}{*}{17.34} & \multirow{2}{*}{$\begin{array}{l}< \\
0.001\end{array}$} \\
\hline & Cancerous & 102 & $30(29.4)$ & $26(25.5)$ & $46(45.1)^{\square}$ & & \\
\hline \multicolumn{8}{|c|}{ Gender } \\
\hline & Male & 70 & $22(31.4)$ & $18(25.7)$ & $30(42.9)$ & \multirow[t]{2}{*}{0.56} & \multirow[t]{2}{*}{0.755} \\
\hline & Female & 32 & $8(25)$ & $8(25)$ & $16(50)$ & & \\
\hline \multicolumn{8}{|c|}{ Smoking } \\
\hline & Yes & 40 & $12(30)$ & $8(20)$ & $20(50)$ & \multirow[t]{2}{*}{1.14} & \multirow[t]{2}{*}{0.567} \\
\hline & No & 62 & $18(29)$ & $18(29)$ & $26(42)$ & & \\
\hline \multicolumn{8}{|c|}{$\begin{array}{l}\text { Pathological } \\
\text { differentiation }\end{array}$} \\
\hline & Poor & 42 & $6(14.3)$ & $8(19)$ & $28(66.7)$ & \multirow[t]{3}{*}{32.18} & \multirow[t]{3}{*}{$\hat{0}_{0.001}$} \\
\hline & Moderate & 38 & $8(21.1)$ & $14(36.8)$ & $16(42.1)$ & & \\
\hline & Well & 22 & $16(72.7)$ & $4(18.2)$ & $2(9.1)$ & & \\
\hline \multicolumn{8}{|c|}{ Lymphatic invasion } \\
\hline & Yes & 38 & $2(5)$ & $4(10)$ & $34(85) \wedge$ & \multirow[t]{2}{*}{44.16} & \multirow{2}{*}{$\begin{array}{l}<.001 \\
0.00\end{array}$} \\
\hline & No & 64 & $28(43.7)$ & $24(37.5)$ & 12(18.8) & & \\
\hline \multicolumn{8}{|l|}{ pTNM } \\
\hline & IIA & 62 & $28(45.2)$ & $24(38.7)$ & $10(16.1)$ & \multirow[t]{2}{*}{52.78} & \multirow{2}{*}{$\begin{array}{l}<.001 \\
0.00\end{array}$} \\
\hline & IIB-IIIA & 40 & $2(5)$ & $2(5)$ & $36(90) \square$ & & \\
\hline \multicolumn{8}{|c|}{$\begin{array}{l}{ }^{\square} p<0.05 \text {, Cancerous tissues compared with normal tissues; }{ }^{\square} p<0.05 \text {, poor differentiated tissues } \\
\text { compared with moderate and well differentiated tissues; }{ }^{\wedge} p<0.05 \text {, N1-3 compared with N0; }{ }^{-} p<0.05 \text {, } \\
\text { IIA compared with IIB-IIIA. }\end{array}$} \\
\hline
\end{tabular}

High expression of Annexin A1 is associated with poor differentiation, lymph node metastasis and advanced clinical stage of LAC 
As shown in Table 2, the expression of Annexin A1 was higher in poorly differentiated (28/42,66.7\%; $p=$ $0.003)$, lymph node metastatic $(34 / 38,85 \% ; p<0.001)$ and IIB-III stage $(36 / 40,90 \% ; p<0.001)$ LAC than that in well differentiated $(2 / 22,9.1 \%)$, non-lymph node metastasis $(12 / 64,18.8 \%)$, and IA-IIA stage LAC $(10 / 62,16.1 \%)$ (Figs. 1F - H).

\section{Expression of Annexin A1 mRNA in LAC tissues is higher than that in normal lung tissues}

The results from Real-time PCR showed that the expression levels of Annexin A1 mRNA in lung cancer tissues and cancer-adjacent normal tissues were $0.568 \pm 1.3212^{-\triangle \Delta C T}$ and $0.251 \pm 0.7892^{-\triangle \Delta C T}$, respectively. The expression of Annexin A1 mRNA in lung cancer tissues was higher than that in canceradjacent normal tissues $(t=3.172, p=0.039)$ (Table 3; Fig. 2A). 
Table 3

Relationship between Annexin A1 mRNA expression and clinicopathological parameters in lung cancer tissues of patients with LAC $(n=102)$

\begin{tabular}{|c|c|c|c|c|c|}
\hline \multirow[t]{2}{*}{ Parameter } & \multirow[t]{2}{*}{ Group } & \multirow[t]{2}{*}{$\mathbf{N}$} & \multicolumn{3}{|c|}{ Annexin A1 mRNA } \\
\hline & & & $2^{-\Delta \Delta C T}$ & $t$ value & $p$ value \\
\hline \multicolumn{6}{|l|}{ Sourse } \\
\hline & Normal & 102 & $0.251 \pm 0.789^{\square}$ & \multirow[t]{2}{*}{3.172} & \multirow[t]{2}{*}{0.039} \\
\hline & Cancerous & 102 & $0.668 \pm 1.321$ & & \\
\hline \multicolumn{6}{|l|}{ Gender } \\
\hline & Male & 70 & $0.682 \pm 1.301$ & \multirow[t]{2}{*}{0.203} & \multirow[t]{2}{*}{0.921} \\
\hline & Female & 32 & $0.702 \pm 1.043$ & & \\
\hline \multicolumn{6}{|l|}{ Smoking } \\
\hline & Yes & 40 & $0.703 \pm 1.082$ & \multirow[t]{2}{*}{0.983} & \multirow[t]{2}{*}{0.603} \\
\hline & No & 62 & $0.673 \pm 1.112$ & & \\
\hline \multicolumn{6}{|c|}{ Pathological differentiation } \\
\hline & Poor & 42 & $1.021 \pm 1.612^{\square}$ & \multirow[t]{3}{*}{10.231} & \multirow[t]{3}{*}{0.001} \\
\hline & Moderate & 38 & $0.712 \pm 1.146$ & & \\
\hline & Well & 22 & $0.487 \pm 1.202$ & & \\
\hline \multicolumn{6}{|c|}{ Lymphatic invasion } \\
\hline & Yes & 38 & $0.911 \pm 1.398 \Delta$ & \multirow[t]{2}{*}{3.178} & \multirow[t]{2}{*}{0.028} \\
\hline & No & 64 & $0.376 \pm 0.893$ & & \\
\hline \multicolumn{6}{|l|}{ pTNM } \\
\hline & $\mid A-\| A$ & 62 & $0.343 \pm 0.856 \square$ & \multirow[t]{2}{*}{6.227} & \multirow[t]{2}{*}{0.021} \\
\hline & IIB-III & 40 & $1.101 \pm 1.532$ & & \\
\hline $\begin{array}{l}{ }^{\square} p<0.05, \mathrm{Ca} \\
\text { with moder } \\
\text { compared } \mathrm{n}\end{array}$ & $\begin{array}{l}\text { h normal tiss } \\
\text { ted tissues; }\end{array}$ & $\begin{array}{l}p< \\
.05,1\end{array}$ & $\begin{array}{l}5 \text {, poor different } \\
-3 \text { compared wit }\end{array}$ & $\begin{array}{l}\text { tissues } \\
\mathbf{\square}_{p \otimes 0.05}\end{array}$ & $\begin{array}{l}\text { apared } \\
\text {-lIA }\end{array}$ \\
\hline
\end{tabular}

Increased Annexin A1 mRNA is associated with poor differentiation, lymph node metastasis and advanced clinical stage of LAC 
The level of Annexin A1 mRNA had nothing to do with the gender and smoking status of LAC patients ( $p$ $>0.05$ ) (Table 3; Figs. 2B and 2C). However, the expression level of Annexin A1 mRNA was higher in poorly differentiated LAC tissues $\left(1.021 \pm 1.6122^{-\triangle A C T}\right)$ than that in well differentiated LAC tissues $\left(0.487 \pm 1.2022^{-\triangle \Delta C T}\right)(t=10.231, p=0.001)$ (Table 3; Fig. 2D). And, the expression level of Annexin A1 mRNA was higher in LAC tissues with lymph node metastasis $\left(0.911 \pm 1.3982^{-\triangle \triangle C T}\right)$ than that in LAC tissues with non-lymph node metastasis $\left(0.376 \pm 0.8982^{-\Delta \Delta C T}\right)(t=3.178, p=0.028)$ (Table 3; Fig. 2E). Moreover, the LAC tissues at IIB-III stage $\left(1.101 \pm 1.5322^{-\triangle \Delta C T}\right)$ showed a higher level of Annexin A1 mRNA compared with the LAC tisssues at IA-IIA stage $\left(0.343 \pm 0.8562^{-\triangle \Delta C T}\right)(t=6.227, p=0.021)$ (Table 3; Fig. 2F).

\section{Serum concentration of Annexin A1 is correlated with the tumor burden of LAC}

The serum concentration of Annexin A1 was higher in poorly differentiated $(6.34 \pm 1.88 \mathrm{ng} / \mathrm{ml}) \mathrm{LAC}$ patients than that in well differentiated patients $(4.05 \pm 1.23 \mathrm{ng} / \mathrm{ml})(p<0.05)($ Table 4; Fig. 3A). The serum concentration of Annexin A1 was higher in LAC patients with lymph node metastasis $(6.11 \pm 1.64$ $\mathrm{ng} / \mathrm{ml}, p<0.05)$ than that in those with non-lymph node metastasis $(4.88 \pm 1.37 \mathrm{ng} / \mathrm{ml})(p<0.05)$ (Table 4; Fig. 3B). The serum concentration of Annexin A1 was higher in LAC patients at IIB-IIIA stage $(6.31 \pm 1.44 \mathrm{ng} / \mathrm{ml})$ than that in those at IIA stage $(\mathrm{ng} / \mathrm{ml})(p<0.05)$ (Table 4; Fig. $3 C)$. Regardless of the pathological grade, the serum Annexin A1 concentration of LAC patients one month after surgery was lower than that before surgery (poorly: $4.11 \pm 1.03$ vs. $6.34 \pm 1.88 \mathrm{ng} / \mathrm{ml}$; moderate: $3.12 \pm 0.95 \mathrm{vs} .3 .92 \pm$ $0.95 \mathrm{ng} / \mathrm{ml}$; well: $3.87 \pm 1.07$ vs. $2.97 \pm 1.07 \mathrm{ng} / \mathrm{ml})(p<0.05)$ (Table 4; Fig. 3D). Regardless of the lymph node metastasis, the serum Annexin A1 concentration of LAC patients one month after surgery was lower than that before surgery (yes: $4.56 \pm 0.99$ vs. $6.11 \pm 1.64 \mathrm{ng} / \mathrm{ml}$; no: $4.03 \pm 1.02$ vs. $4.88 \pm 1.37 \mathrm{ng} / \mathrm{ml})(p<$ 0.05) (Table 4; Fig. 3E). Regardless of the clinical stage, the serum Annexin A1 concentration of LAC patients one month after surgery showed a decrease compared with before surgery (IIA: $3.78 \pm 0.87$ vs. $4.92 \pm 1.05 \mathrm{ng} / \mathrm{ml}$; IIB-IIIA: $4.17 \pm 1.06$ vs. $6.31 \pm 1.44 \mathrm{ng} / \mathrm{ml})(p<0.05)$ (Table 4; Fig. 3F). 
Table 4

Correlation between the serum level of annexin $A 1$ and the surgery treatment of $\operatorname{LAC}(N=102)$ Groups Items

$\mathrm{N}$ Serum concentrations of annexin $\mathrm{A} 1 \mathrm{M} \pm \mathrm{SD}(\mathrm{ng} / \mathrm{ml})$

Before surgery One month after surgery

Pathologic grade

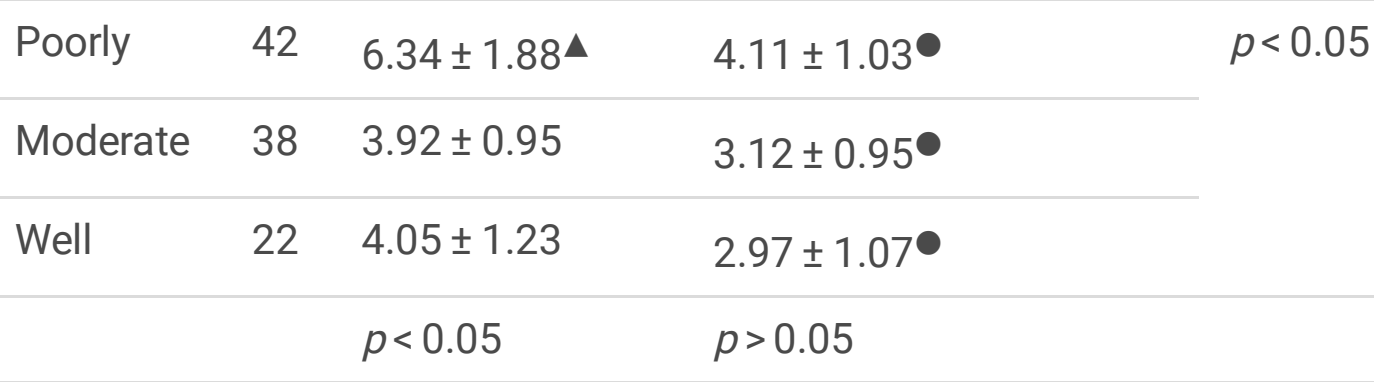

Lymph node metastasis

$\begin{array}{lllll}\text { Yes } & 38 & 6.11 \pm 1.64 \boldsymbol{\Lambda} & 4.56 \pm 0.99 \bullet \bullet & p<0.05 \\ \text { No } & 64 & 4.88 \pm 1.37 & 4.03 \pm 1.02 \bullet \bullet & \\ & & p<0.05 & p>0.05 & \end{array}$

pTNM stage

$\begin{array}{lllll}\text { IIA } & 62 & 4.92 \pm 1.05 & 3.78 \pm 0.87 \bullet \bullet \bullet & p<0.05 \\ \text { HIB-IIIA } & 40 & 6.31 \pm 1.44 \boldsymbol{\Lambda \Lambda \Lambda} & 4.17 \pm 1.06 \bullet \bullet \bullet & \\ & & p<0.05 & p>0.05 & \end{array}$

$\mathrm{LAC}$, adenocarcinoma of the lung; $\mathrm{M} \pm \mathrm{SD}$, mean \pm standard deviation; $\mathbf{\Delta}$ : poorly compared with moderate and well; $\mathbf{\Lambda \Lambda}$ : no lymph node metastasis compared with lymph node metastasis; $\mathbf{\Lambda \Lambda \Lambda}$ : IIBIIIA compared with IIA; $\bullet$ : comparison after surgery and before surgery; $\bullet^{\bullet \bullet}$ : comparison after surgery and before surgery; $\bullet^{\bullet \bullet}$ : comparison after surgery and before surgery; TNM, Tumor-Node-Metastasis.

\section{Chemotherapy of LAC decreases the serum concentration of Annexin A1}

The serum Annexin A1 concentration of patients without starting chemotherapy did not show statistical significance in the subgroup analysis (Table 5; Figs. 4A - C). Regardless of the pathological grade, the serum Annexin A1 concentration of LAC patients after chemotherapy was lower than that before chemotherapy (poorly: $3.31 \pm 0.99$ vs. $4.76 \pm 1.11 \mathrm{ng} / \mathrm{ml}$; Moderate: $3.12 \pm 0.78$ vs. $4.21 \pm 1.04 \mathrm{ng} / \mathrm{ml}$; well: $3.09 \pm 0.84$ vs. $4.13 \pm 1.19 \mathrm{ng} / \mathrm{ml})(p<0.05)$ (Table 5; Fig. 4D). And, regardless of the lymph node metastasis, the serum Annexin A1 concentration of LAC patients after chemotherapy was lower than that before chemotherapy (yes: $3.29 \pm 1.09$ vs. $4.31 \pm 1.38 \mathrm{ng} / \mathrm{ml}$; no: $3.33 \pm 0.92$ vs. $4.27 \pm 1.17 \mathrm{ng} / \mathrm{ml})(p<$ 0.05) (Table 5; Fig. 4E). Moreover, regardless of the clinical stage, the serum Annexin A1 concentration of 
LAC patients after chemotherapy showed a decrease compared with before chemotherapy (IIA: $2.91 \pm$ 0.67 vs. $3.98 \pm 0.78 \mathrm{ng} / \mathrm{ml}$; IIB-IIIA: $3.39 \pm 0.93$ vs. $4.46 \pm 1.31 \mathrm{ng} / \mathrm{ml})(p<0.05)($ Table $5 ;$ Fig. 4F).

Table 5

Correlation between the serum level of annexin A1 and the chemotherapy treatment of LAC $(N=51)$

\begin{tabular}{|c|c|c|c|c|}
\hline \multirow[t]{2}{*}{ Groups } & \multirow[t]{2}{*}{ Items } & \multirow[t]{2}{*}{$\mathbf{N}$} & \multicolumn{2}{|c|}{ Serum concentrations of annexin $\mathrm{A} 1 \mathrm{M} \pm \mathrm{SD}(\mathrm{ng} / \mathrm{ml})$} \\
\hline & & & $\begin{array}{l}\text { Before } \\
\text { chemotherapy }\end{array}$ & $\begin{array}{l}\text { After four cycles of chemotherapy } \\
\text { (Pemetrexed + Cisplatin) }\end{array}$ \\
\hline & & & $\begin{array}{l}\text { (1 month after } \\
\text { surgery) }\end{array}$ & \\
\hline
\end{tabular}

Pathologic

grade

$\begin{array}{lccll}\text { Poorly } & 21 & 4.76 \pm 1.11 & 3.31 \pm 0.99 \bullet & \begin{array}{c}p< \\ 0.05\end{array} \\ \text { Moderate } & 19 & 4.21 \pm 1.04 & 3.12 \pm 0.78 \bullet & \\ \text { Well } & 11 & 4.13 \pm 1.19 & 3.09 \pm 0.84 \bullet \\ & & p>0.05 & p>0.05 & \end{array}$

Lymphatic

invasion

$\begin{array}{lllll}\text { Yes } & 19 & 4.31 \pm 1.38 & 3.29 \pm 1.09 \bullet \bullet & p< \\ & & & \\ \text { No } & 32 & 4.27 \pm 1.17 & 3.33 \pm 0.92 \bullet \bullet & \\ & & p>0.05 & p>0.05 & \end{array}$

TNM stage

$\begin{array}{lllll}\text { IIA } & 31 & 3.98 \pm 0.78 & 2.91 \pm 0.67 \bullet \bullet \bullet & p< \\ \text { IIB-HIA } & 20 & 4.46 \pm 1.31 & 3.39 \pm 0.93 \bullet \bullet \bullet & \\ & & p>0.05 & p>0.05 & \end{array}$

$\mathrm{LAC}$, adenocarcinoma of the lung; $\mathrm{M} \pm \mathrm{SD}$, mean \pm standard deviation; $\bullet$ : after chemotherapy compared with before chemotherapy; ${ }^{\bullet \bullet}$ : after chemotherapy compared with before chemotherapy; ๑००: after chemotherapy compared with before chemotherapy; TNM, Tumor-Node-Metastasis.

Expression of Annexin A1 in LAC tissues and cells shows an increase compared with normal lung tissues and $16 \mathrm{HBE}$ cells by western blotting

Compared with normal lung tissues adjacent to cancer, Annexin A1 in LAC tissues was significantly increased $(p<0.05)$ (Fig. 5A and B). Compared with 16HBE cells, the expression of Annexin A1 in LAC A549 cells $(p<0.05)$ (Fig. 5C and D) and PC-9 cells $(p<0.05)$ (Fig. 5E and F) was also significantly 
increased. In addition, the expression of Annexin A1 in lung squamous cell carcinoma H520 cells and small cell lung cancer $\mathrm{H} 446$ cells was also higher than that in 16HBE cells, but the increase was not as high as LAC cells.

\section{Discussion}

The development and progression of LAC have been confirmed to be a multi-gene, multi-step, multi-stage process. It has been gradually realized that lung cancer may be a disease that develops from external causes through internal causes. The external factors can induce malignant transformation of cells and irreversible genetic changes, including the activation of proto-oncogenes, the inactivation of tumor suppressor genes, the activation of self-feedback secretion loops and the inhibition of cell apoptosis, leading to uncontrolled cell growth [2-4]. The proliferation activity of tumor cells is closely related to the biological behavior of tumors. Uncontrolled cell proliferation is the most basic feature of the occurrence, invasion and metastasis of malignant tumors. This process is related to the abnormal expression of proteins translated by many oncogenes $[2,11]$. In this study, we found that Annexin A1 was highly expressed in LAC tissues. The results indicated that Annexin A1 may have played a role in the progression of LAC, thus correlating with the occurrence and development of LAC. Some previous studies have suggested that the increase in Annexin A1 is related to the tumorigenesis of lung cancer, including lung squamous cell carcinoma and small cell lung cancer [11-14]. Our study showed that the expression of Annexin A1 was related to the malignant biological behavior of $L A C$, including poor differentiation, lymph node metastasis and advanced clinical stage of LAC, suggesting that the expression of Annexin A1 can be considered as a tumor marker to predict the disease progression and prognosis of LAC. Poor differentiation, lymph node metastasis, and advanced disease all indicate the malignant characteristics of tumors and have a worse prognosis. Our research suggests that Annexin A1 can be used to predict the degree of malignancy of LAC, and has certain prognostic evaluation value. Studies have shown that Annexin A1 is closely related to a variety of malignant tumors. It may be involved in the occurrence and development of tumors, and is closely related to tumor differentiation, proliferation, invasion, metastasis and tumor prognosis [15].

We especially observed that the expression of Annexin A1 mRNA in LAC tissue is also higher than that in normal lung tissue. And the high level of Annexin A1 mRNA was related to the poor differentiation of LAC, lymph node metastasis and advanced clinical stage. The mRNA is a general term for a large class of RNA molecules, which are responsible for transmitting genetic information from DNA to ribosomes, and then producing proteins encoded by genes on the ribosomes. Then, RNA polymerase transcribes genes into mRNA precursors. The mRNA precursors are processed into mature RNAs and translated into specific proteins [16]. Although mRNA and protein levels are a coupled process, there is no necessarily consistent trend between the two. The increase in mRNA level represents the activation of promoters or enhancers, or the activation of upstream transcription factors, while the increase in protein levels is mostly related to functional enhancement. The transcription of mRNA and the process of protein translation are coupled with each other, so verifying the relationship between the two is quite powerful for confirming the activation of a certain gene $[16,17]$. Our research showed that the expressions of Annexin A1 mRNA and 
protein were consistent, which illustrates that this gene plays a certain role in the occurrence and development of LAC.

We found that the concentration of Annexin A1 in the patient's serum was related to the poor differentiation of LAC, lymph node metastasis and later clinical stage. More importantly, the serum Annexin A1 concentration in LAC patients one month after surgery was significantly lower than that before surgery. Surgical removal of tumors plays an important role in reducing tumor burden, restoring the body's immune function, and improving the effect of immunotherapy. The expressions of various costimulatory molecules were significantly reduced. Surgical removal of tumors can reduce the adverse effects of many tumor-related substances on the human body, and the long-term effect is to improve the body's immune function [18-20]. Our findings indicate that Annexin A1 is closely related to the malignant biological behavior of LAC. The serum concentration drops after tumor resection, which indirectly indicates the benefit of the rapid reduction in the body's tumor load after surgery. We also found that pemetrexed combined with cisplatin chemotherapy further suppressed the concentration of serum Annexin A1. Chemotherapy plays an important role in killing the remaining tumor cells after surgery. Our finding further indicates that Annexin A1 is related to the progression of LAC. After chemotherapy, the serum concentration of Annexin A1 further reduced, which can also reflect the therapeutic effect of chemotherapy on tumors from the side. Studies show that Annexin A1 is a multifunctional protein characterized by its role in regulating innate and adaptive immune responses. Evidence of increased expression of Annexin A1 in many human tumors has aroused interest in its functional role in cancer biology $[5,7]$. Annexin A1 can regulate the polarization and activation of macrophages, and acts through its receptor FPR2 to promote the polarization of macrophages. Annexin A1-deficient mice showed a decrease in tumor growth rate, which may be due to the increase of M1 macrophages in the tumor microenvironment [21]. Pemetrexed is a multi-target folate antagonist that inhibits cell replication by disrupting the key folate-dependent metabolic process necessary for cell replication. The chemotherapy regimen of pemetrexed plus cisplatin is the first-line treatment regimen for advanced LAC, which is better than the chemotherapy regimen of gemcitabine plus cisplatin, paclitaxel plus cisplatin, and docetaxel plus cisplatin $[22,23]$. The finding that serum concentration of Annexin A1 further decreases after chemotherapy can reflect that Annexin A1 is related to the progress of LAC, and its down-regulation after chemotherapy implies that the further killing degree of LAC cells can to be correlated by the serum level of Annexin A1. Patients with metastatic renal cell carcinoma are usually treated with the tyrosine kinase inhibitor sunitinib. A study suggests that Annexin A1-negative tumors can get longer treatment benefits, and the overall survival of patients with Annexin A1-negative tumors is also significantly better. This study shows that the cytoplasmic expression of Annexin A1 is a negative predictor of sunitinib treatment in patients with metastatic renal cell carcinoma [24]. A study suggests that the overexpression of Annexin A1 is significantly related to the advanced clinical stages of LAC and lymph node metastasis, an increase in recurrence rate and overall survival. In addition, siRNA interference to Annexin A1 significantly inhibites the invasion ability of LAC cells A549 in vitro [25].

We further verified the expression of Annexin A1 in tissues and cells by Western blotting. Compared with normal lung tissue adjacent to cancer and 16HBE cells, Annexin A1 expression in LAC tissues and cells 
was significantly increased. These results further reinforces this evidence that Annexin A1 expression is increased in LAC, and it also further strengthens the idea that it may be used as a molecular marker of LAC. Some basic research at the cellular level has gradually consolidated the chain of evidence linking Annexin $\mathrm{A} 1$ to the proliferation and invasion of malignant tumors. Studies used RNA interference technology to down-regulate the expression of Annexin A1 in A549 and H1299 cells of NSCLC showed that the knockdown of Annexin A1 gene inhibited the proliferation, migration and invasion of NSCLC cells $[5,25]$. The Annexin A1 overexpression plasmid was used to transfect esophageal squamous cell carcinoma (ESCC) Eca109 cells, which increased the expression of Annexin A1 in Eca109 cells.

Subsequent observations showed that the proliferation, migration and invasion of Eca109 cells increased significantly and proved that Annexin A1 promoted the expression of Snail but inhibited the expression of E-cadherin, thereby enhancing the migration and invasion of ESCC cells [26]. In the process of tumorigenesis, how to control the rate of tumor cell migration, invasion and apoptosis is a focus of current research on tumor molecular biology. Annexin A1 has a certain effect on the migration, invasion and apoptosis of LAC cells, which may provide research ideas for the development of molecular targeted therapy based on it. Some of the shortcomings of this study are as follows. This study did not conduct studies on Annexin A1 functions at the level of LAC cells and model animals. We plan to carry out research in this area in the future. The initial design of this study was limited to the study of LAC, and no study on Annexin A1 in squamous cell carcinoma and small cell lung cancer was carried out. This also suggests that we can expand the scope of research in the next step.

\section{Conclusions}

Increase Annexin A1 protein and mRNA in LAC tissues correlate with the poor differentiation, lymph node metastasis and advanced stage of LAC. LAC cells show an increased Annexin A1 compared with 16HBE cells. However, surgical resection and chemotherapy decreases the serum concentration of Annexin A1 in LAC patients. The results indicate that expression level of Annexin A1 contributes to the evaluation of the disease progression and treatment effect of LAC.

\section{Abbreviations}

16-HBE, 16 human bronchial epithelial cell lines; A549 cells,human adenocarcinoma cells; ESCC, esophageal squamous cell carcinoma; FRR2, $\mathrm{N}$-formyl peptide receptor 2; IHC, immunohistochemistry; LAC, lung adenocarcinoma; NSCLC, non-small cell lung cancer; PC-9 cells, human adenocarcinoma cells; PBS, phosphate buffer saline; PVDF, polyvinylidene difluoride; RNA, ribonucleic acid; SCLC, small cell lung cancer; RT-PCR, Real-time quantitative PCR.

\section{Declarations}

\section{Ethics approval and consent to participate}


The study was approved by the Ethics Committee, the First Hospital, Xi'an Medical University. All research specimens from patients were authorized by the patients and signed informed consents. This study was performed strictly following the Statement of Strengthening the Reporting of Observational Studies in Epidemiology (STROBE). We declare that all research strategies and methods used in this study were performed in accordance with the relevant guidelines and regulations.

\section{Consent to publish}

Not applicable.

\section{Availability of data and materials}

The datasets supporting the conclusions of this article are included within the article. The datasets used and/or analysed during the current study are available from the corresponding author on reasonable request.

\section{Competing interests}

None.

\section{Funding}

This study was supported by grants from the Medical Project of the Xi'an Science and Technology Bureau (XA2020-YXYJ-0163). The fund provider did not play any role in this study, nor did it participate in any matters in this study.

\section{Authors' contributions}

$B X R, H L Y, G W, K L, M L, C X R$, and $W L$ participated in the design and coordination of the study, carried out the critical appraisal of studies, statistical analysis of studies and wrote the manuscript. All authors have read and approved the manuscript, and ensure that this is the case.

\section{Acknowledgements}

We appreciate the great help of Dr. W DL and Miss Z M as interviewers.

Address correspondence to: Biaoxue Rong, Department of Oncology, First Affiliated Hospital, Xi'an Medical University, Xi'an, China, 48 Fenghao West Road, Xi'an 710077, China. Tel: +86 029-87679300; Email: research568rbx@yeah.net

\section{References}

1. Chen W, Zheng R, Baade PD, Zhang S, Zeng H, Bray F, Jemal A, Yu XQ, He J: Cancer statistics in China, 2015. CA Cancer J Clin 2016, 66(2):115-132. 
2. Hirsch FR, Scagliotti GV, Mulshine JL, Kwon R, Curran WJ, Jr., Wu YL, Paz-Ares L: Lung cancer: current therapies and new targeted treatments. Lancet 2016.

3. Nanavaty P, Alvarez MS, Alberts WM: Lung cancer screening: advantages, controversies, and applications. Cancer Control 2014, 21(1):9-14.

4. Lemjabbar-Alaoui $\mathrm{H}$, Hassan OU, Yang YW, Buchanan P: Lung cancer: Biology and treatment options. Biochim Biophys Acta 2015, 1856(2):189-210.

5. Biaoxue R, Xiguang $C$, Shuanying Y: Annexin A1 in malignant tumors: current opinions and controversies. Int J Biol Markers 2014, 29(1):e8-20.

6. Tu Y, Johnstone CN, Stewart AG: Annexin A1 influences in breast cancer: Controversies on contributions to tumour, host and immunoediting processes. Pharmacol Res 2017, 119:278-288.

7. Foo SL, Yap G, Cui J, Lim LHK: Annexin-A1 - A Blessing or a Curse in Cancer? Trends Mol Med 2019, 25(4):315-327.

8. Moraes LA, Ampomah PB, Lim LHK: Annexin A1 in inflammation and breast cancer: a new axis in the tumor microenvironment. Cell Adh Migr 2018, 12(5):417-423.

9. Duan N.

10. Biaoxue R, Xiling J, Shuanying Y, Wei Z, Xiguang C, Jinsui W, Min Z: Upregulation of Hsp90-beta and annexin A1 correlates with poor survival and lymphatic metastasis in lung cancer patients. J Exp Clin Cancer Res 2012, 31:70.

11. Leoni G, Alam A, Neumann PA, Lambeth JD, Cheng G, McCoy J, Hilgarth RS, Kundu K, Murthy N, Kusters D et al: Annexin A1, formyl peptide receptor, and NOX1 orchestrate epithelial repair. J Clin Invest 2013, 123(1):443-454.

12. Chen $P$, Min J, Wu H, Zhang H, Wang $C$, Tan G, Zhang F: Annexin A1 is a potential biomarker of bone metastasis in small cell lung cancer. Oncol Lett 2021, 21(2):141.

13. Guan X, Fang Y, Long J, Zhang Y: Annexin 1-nuclear factor-kB-microRNA-26a regulatory pathway in the metastasis of non-small cell lung cancer. Thorac Cancer 2019, 10(4):665-675.

14. Fang Y, Guan X, Cai T, Long J, Wang H, Xie X, Zhang Y: Knockdown of ANXA1 suppresses the biological behavior of human NSCLC cells in vitro. Mol Med Rep 2016, 13(5):3858-3866.

15. Ganesan T, Sinniah A, Ibrahim ZA, Chik Z, Alshawsh MA: Annexin A1: A Bane or a Boon in Cancer? A Systematic Review. Molecules 2020, 25(16).

16. Kaczmarek JC, Kowalski PS, Anderson DG: Advances in the delivery of RNA therapeutics: from concept to clinical reality. Genome Med 2017, 9(1):60.

17. Maier T, Güell M, Serrano L: Correlation of mRNA and protein in complex biological samples. FEBS Lett 2009, 583(24):3966-3973.

18. Masiak-Segit W, Rawicz-Pruszyński K, Skórzewska M, Polkowski WP: Surgical treatment of pancreatic cancer. Pol Przegl Chir 2018, 90(2):45-53.

19. Wei WI, Chan JYW: Surgical Treatment of Advanced Staged Hypopharyngeal Cancer. Adv Otorhinolaryngol 2019, 83:66-75. 
20. Hoy H, Lynch T, Beck M: Surgical Treatment of Lung Cancer. Crit Care Nurs Clin North Am 2019, 31(3):303-313.

21. Moraes LA, Kar S, Foo SL, Gu T, Toh YQ, Ampomah PB, Sachaphibulkij K, Yap G, Zharkova O, Lukman $\mathrm{HM}$ et al: Annexin-A1 enhances breast cancer growth and migration by promoting alternative macrophage polarization in the tumour microenvironment. Sci Rep 2017, 7(1):17925.

22. Mok TS, Wu YL, Ahn MJ, Garassino MC, Kim HR, Ramalingam SS, Shepherd FA, He Y, Akamatsu H, Theelen WS et al: Osimertinib or Platinum-Pemetrexed in EGFR T790M-Positive Lung Cancer. The New England journal of medicine 2017, 376(7):629-640.

23. Shih JY, Inoue A, Cheng R, Varea R, Kim SW: Does Pemetrexed Work in Targetable, Nonsquamous Non-Small-Cell Lung Cancer? A Narrative Review. Cancers (Basel) 2020, 12(9).

24. Niinivirta M, Enblad G, Edqvist PH, Pontén F, Dragomir A, Ullenhag GJ: Tumoral ANXA1 Is a Predictive Marker for Sunitinib Treatment of Renal Cancer Patients. J Cancer 2017, 8(19):3975-3983.

25. Liu YF, Zhang PF, Li MY, Li QQ, Chen ZC: Identification of annexin A1 as a proinvasive and prognostic factor for lung adenocarcinoma. Clin Exp Metastasis 2011, 28(5):413-425.

26. Han G, Lu K, Huang J, Ye J, Dai S, Ye Y, Zhang L: Effect of Annexin A1 gene on the proliferation and invasion of esophageal squamous cell carcinoma cells and its regulatory mechanisms. Int $\mathrm{J} \mathrm{Mol}$ Med 2017, 39(2):357-363.

\section{Figures}
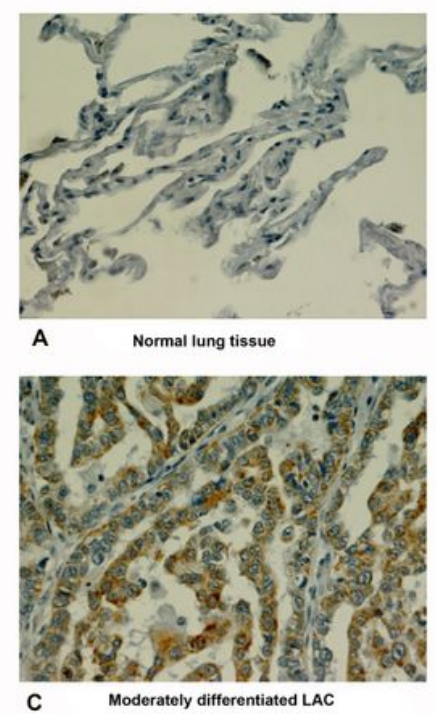

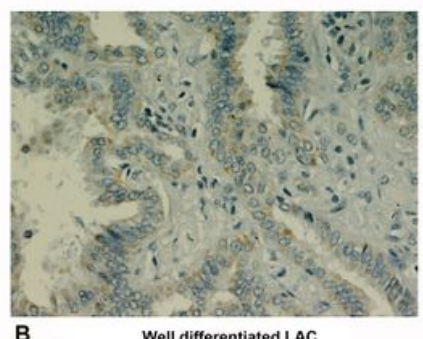

Well differentiated LAC

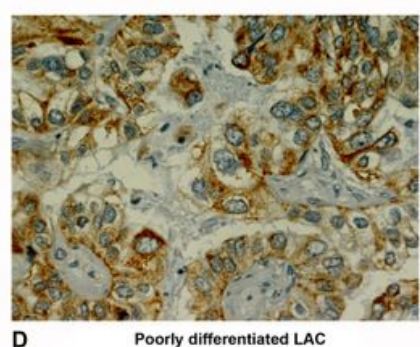

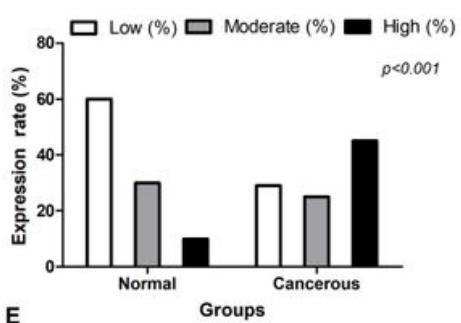

E

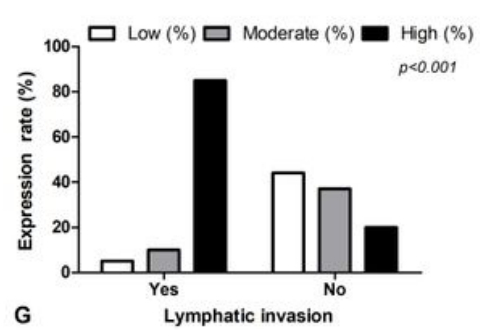

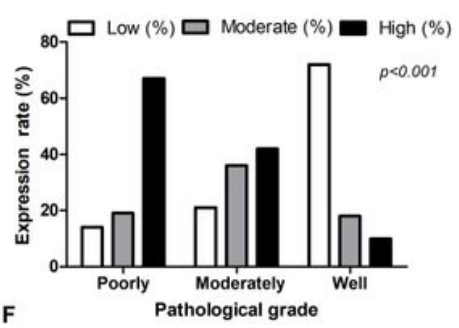

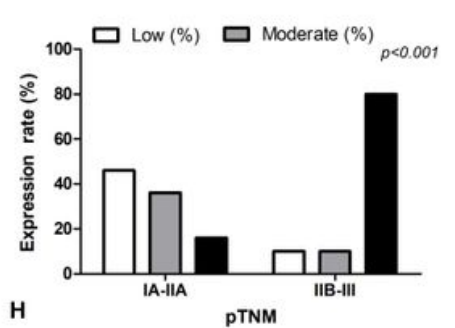

Figure 1

$\mathrm{IHC}$ analysis of Annexin $\mathrm{A} 1$ in $\mathrm{LAC}$ and normal lung tissues $(\mathrm{IHC} \times 400)$ A. No staining of Annexin $\mathrm{A} 1 \mathrm{in}$ normal lung tissues. B. Low staining of Annexin A1 in well differentiated LAC. C. Moderate staining of Annexin A1 in moderately differentiated LAC. D. High staining of Annexin A1 in poorly differentiated LAC. $E$. The expression of Annexin A1 in LAC tissues was higher than that in normal lung tissues $(p<0.01)$. $F$. 
The expression of Annexin A1 was higher in the poor differentiated LAC tissues than in moderately and well differentiated LAC $(p<0.01)$. G. The expression of Annexin A1 was higher in the non-lymph node metastasis LAC tissues than in lymph node metastasis LAC tissues $(p<0.01) ; \mathrm{H}$. the expression of Annexin A1 was higher in IIB-IIIA stage LAC tissues than in IIA stage tissues $(p<0.01)$. LAC, lung adenocarcinoma.

A

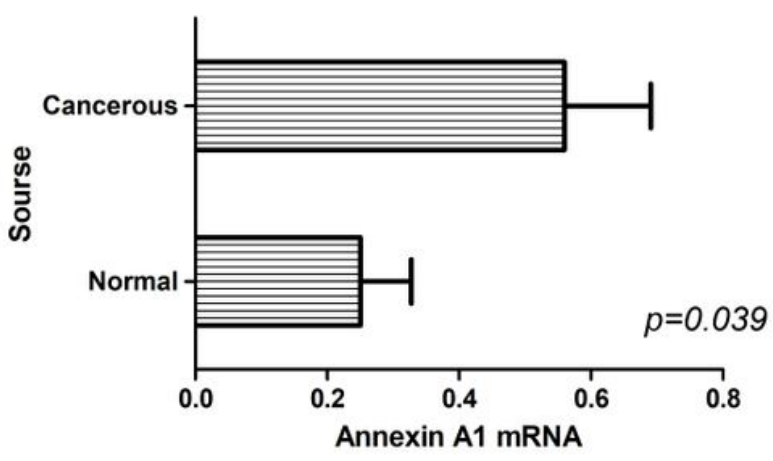

C

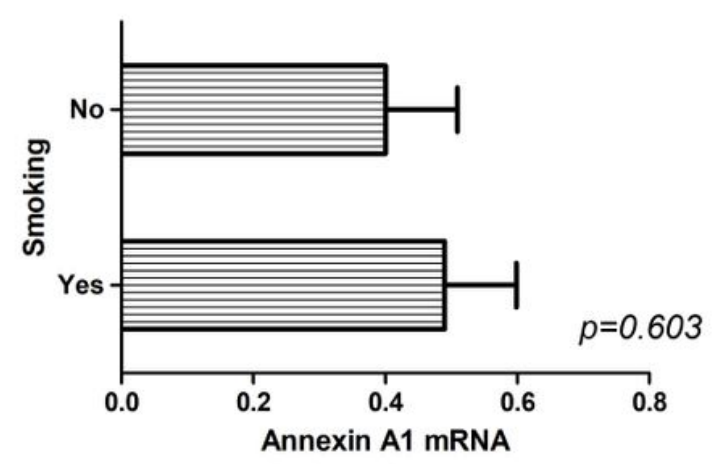

$\mathbf{E}$

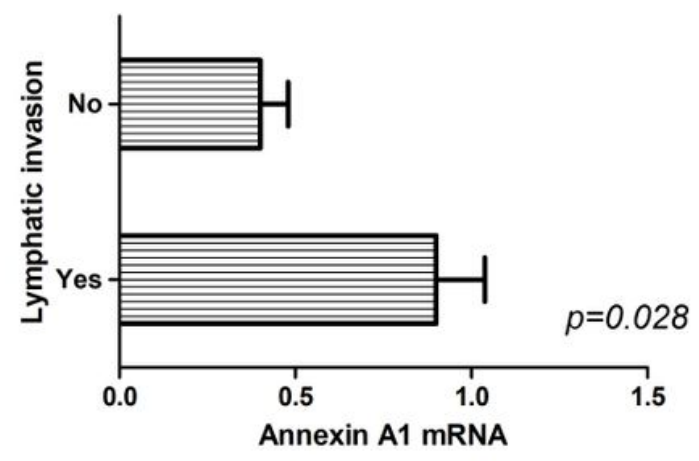

B
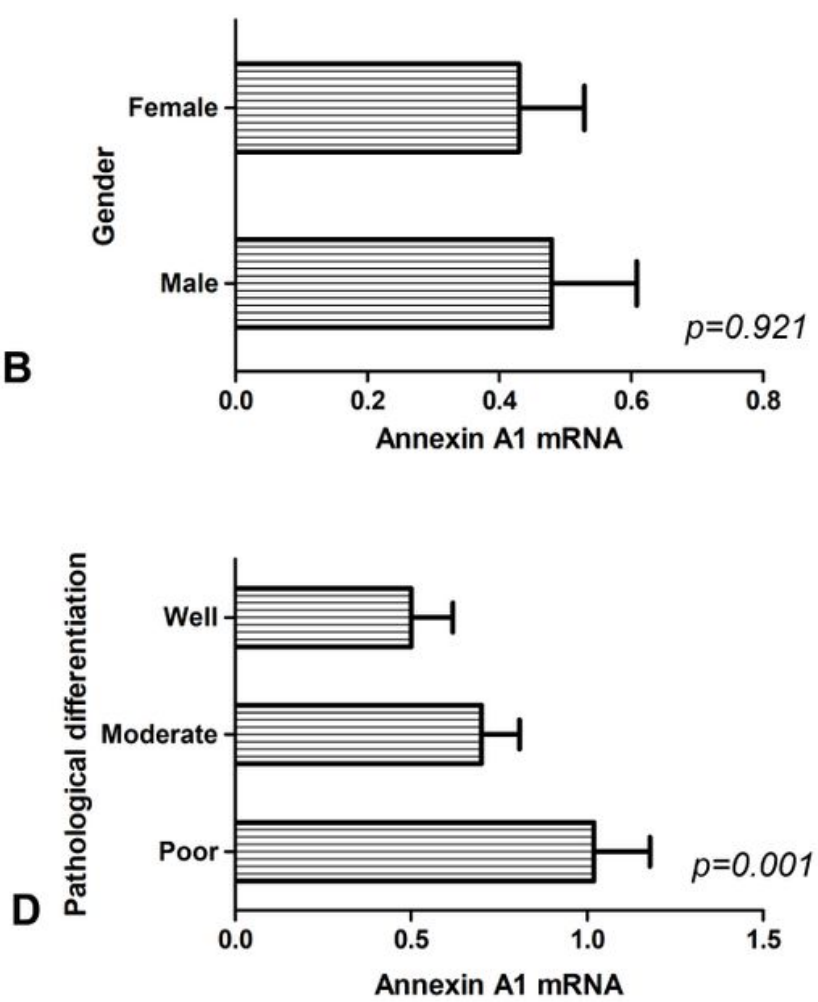

$\mathbf{F}$

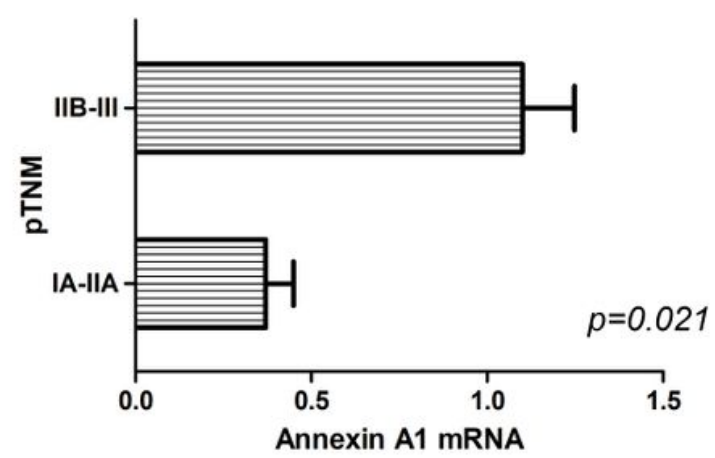

Figure 2

Expression of Annexin A1 mRNA in LAC tissues correlates with malignant biological characteristics of LAC A. the expression of Annexin A1 mRNA in LAC tissues was higher than that in normal lung tissues $(p<0.05)$; $B$. the expression of Annexin A1 mRNA in lung cancer tissues has nothing to do with the gender of the patient ( $p>0.05)$; $C$. the expression of Annexin A1 mRNA in lung cancer tissues has nothing to do with the smoking status of the patients ( $p>0.05)$; D. the expression of Annexin A1 mRNA was higher in the 
poor differentiated LAC tissues than in moderately and well differentiated LAC $(p<0.05)$; E. the expression of Annexin A1 mRNA was higher in LAC tissues with lymph node metastasis than in those without lymph node metastasis LAC tissues ( $p<0.05)$; $F$. the expression of Annexin A1 mRNA was higher in IIB-IIIA stage LAC tissues than in IIA stage tissues $(p<0.05)$. LAC, lung adenocarcinoma.
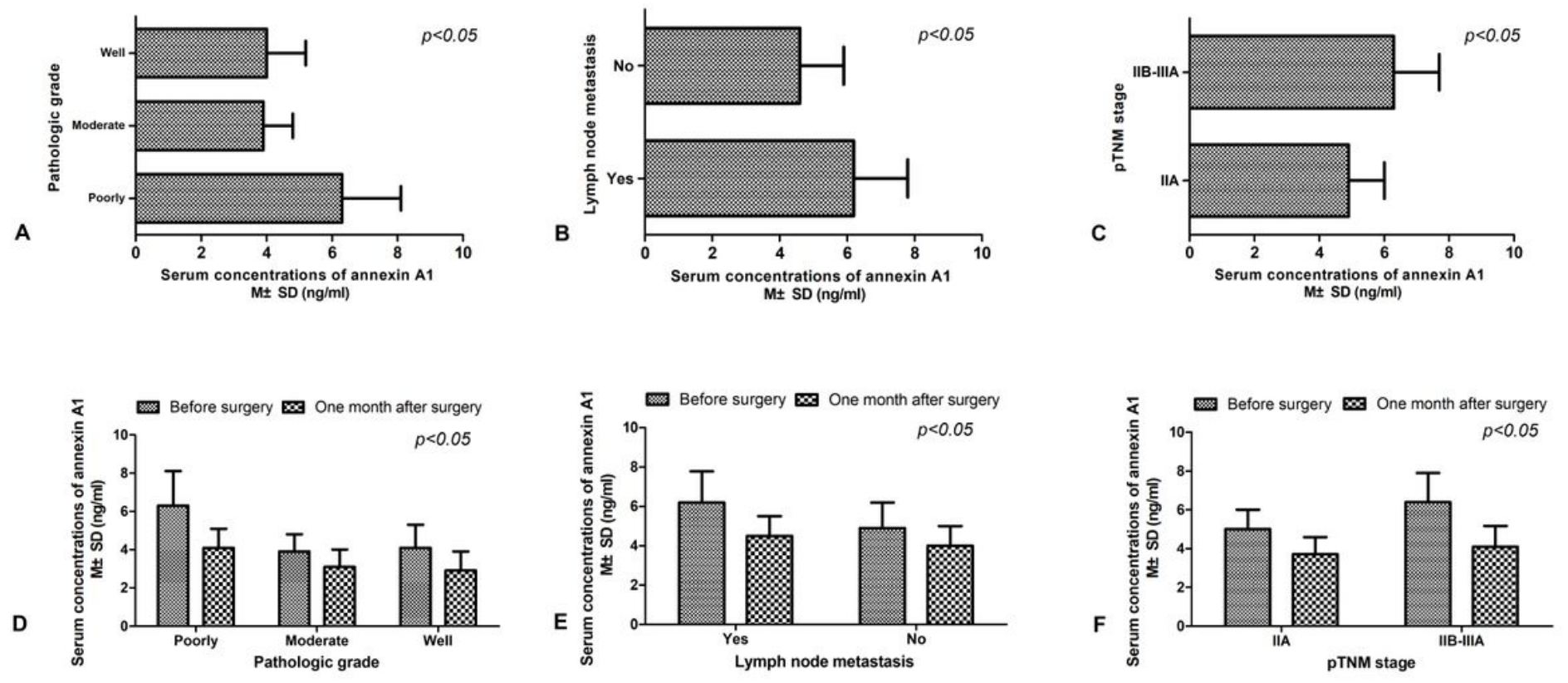

Figure 3

Relationship between the serum concentration of Annexin A1 and the resection of LAC A. the serum concentration of Annexin A1 was higher in the poor differentiated LAC patients than in moderately and well differentiated patients $(p<0.05)$; B. the serum concentration of Annexin A1 was higher in LAC patients with lymph node metastasis than in those without lymph node metastasis $(p<0.05) ; C$. the serum concentration of Annexin A1 was higher in IIB-IIIA stage LAC tissues than in IIA stage tissues $(p<0.05)$; D. Regardless of the degree of differentiation of LAC, the serum concentration of Annexin A1 in patients 1 month after LAC surgery was lower than before surgery $(p<0.05)$; E. Regardless of the status of lymph node metastasis, the serum concentration of Annexin A1 in patients 1 month after LAC surgery was lower than before surgery $(p<0.05)$; $F$. Regardless of the clinical stage of $L A C$, the serum concentration of Annexin $A 1$ in patients 1 month after LAC surgery was lower than before surgery $(p<0.05)$. LAC, lung adenocarcinoma. 

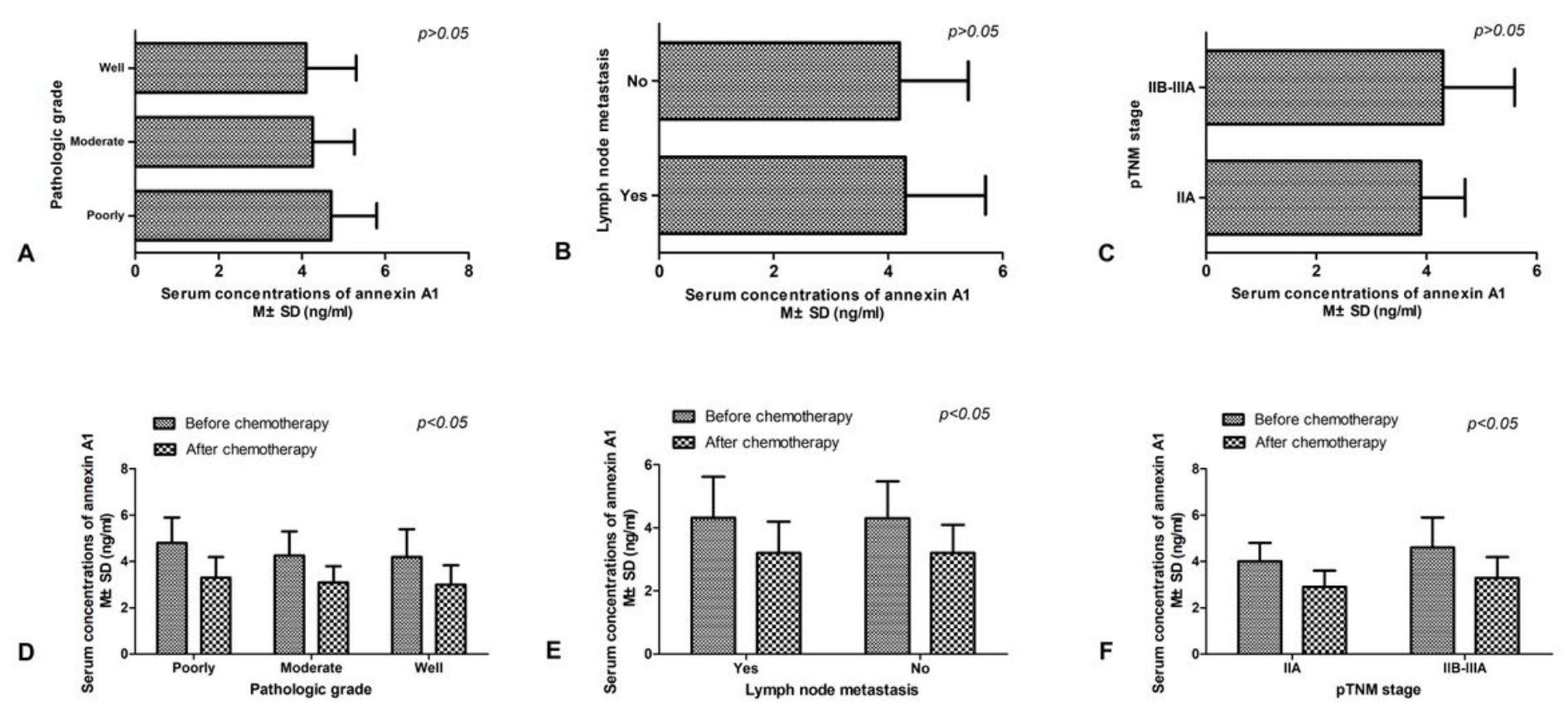

\section{Figure 4}

Relationship between the serum concentration of Annexin A1 and chemotherapy of LAC A. before chemotherapy, the serum concentration of Annexin A1 was higher in the poor differentiated LAC patients than in moderately and well differentiated patients $(p<0.05)$; B. before chemotherapy, the serum concentration of Annexin A1 was higher in LAC patients with lymph node metastasis than in those without lymph node metastasis ( $p<0.05)$; $C$. before chemotherapy, the serum concentration of Annexin A1 was higher in IIB-IIIA stage LAC tissues than in IIA stage tissues $(p<0.05)$; $D$. Regardless of the degree of differentiation of LAC, the serum concentration of Annexin A1 in patients after chemotherapy was lower than before chemotherapy $(p<0.05)$; E. Regardless of the status of lymph node metastasis, the serum concentration of Annexin A1 in patients after chemotherapy was lower than before chemotherapy $(p<0.05)$; F. Regardless of the clinical stage of LAC, the serum concentration of Annexin A1 in patients after chemotherapy was lower than before chemotherapy $(p<0.05)$. LAC, lung adenocarcinoma. 

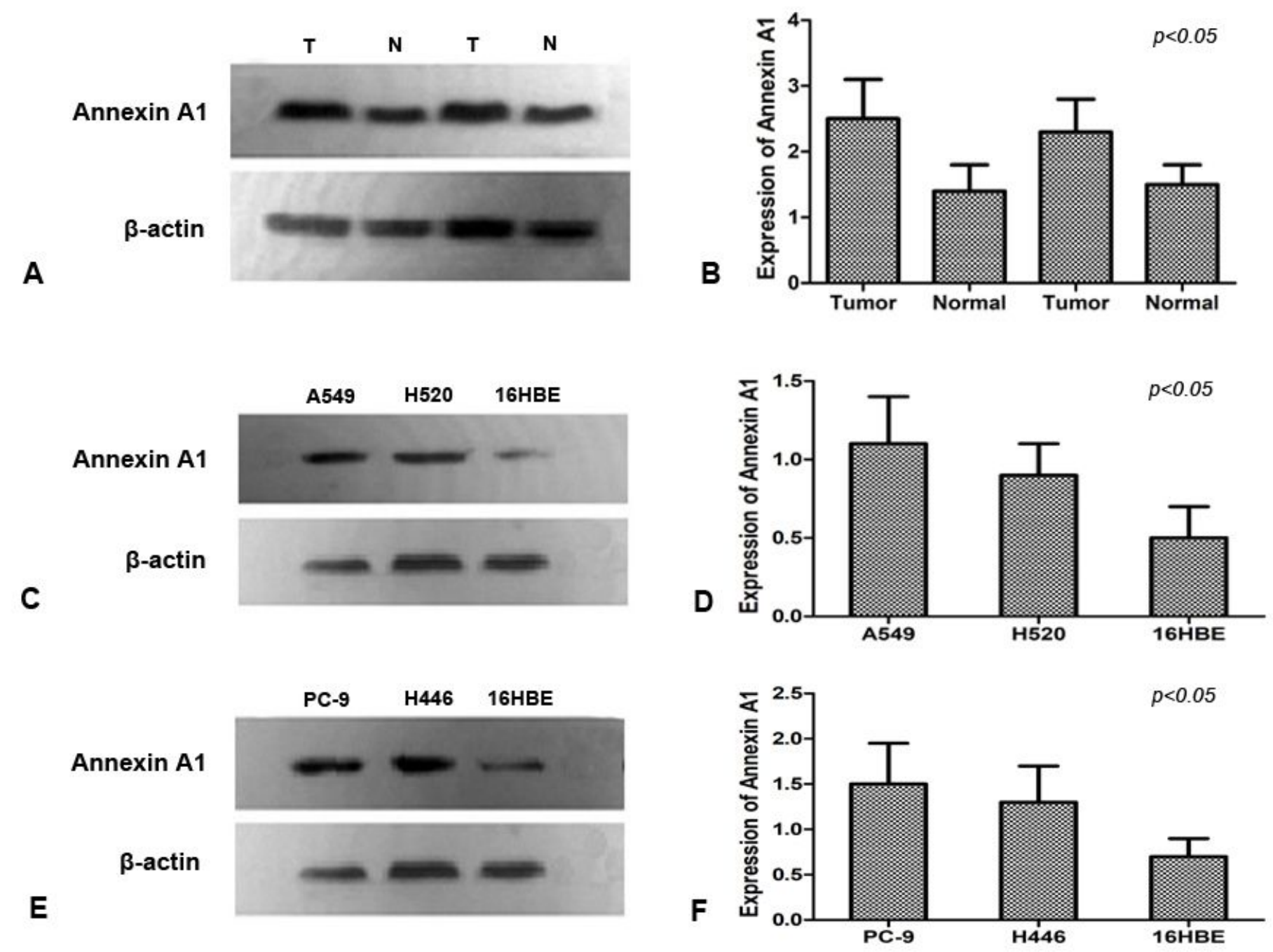

Figure 5

Expression of Annexin A1 in lung adenocarcinoma tissues and cells by Western Blot A and B. Compared with normal lung tissues adjacent to cancer, Annexin A1 expression in LAC tissues was significantly increased $(p<0.05)$. C and D. Compared with $16 \mathrm{HBE}$ cells, the expression of Annexin A1 in LAC A549 cells was significantly increased $(p<0.05)$; the expression of Annexin $A 1$ in lung squamous cell carcinoma H520 cells was also higher than that in 16HBE cells, but the increase was not as high as LAC cells. E and F. Compared with $16 \mathrm{HBE}$ cells, the expression of Annexin A1 in LAC PC-9 cells was significantly increased $(p<0.05)$; the expression of Annexin A1 in small cell lung cancer $\mathrm{H} 446$ cells was also higher than that in $16 \mathrm{HBE}$ cells, but the increase was not as high as LAC cells. LAC, lung adenocarcinoma; $16 \mathrm{HBE}, 16$ human bronchial epithelial. 